\title{
CATALYTIC WAVE OF CHLORATE IONS IN THE PREZENCE OF THE MOLYBDENUM (VI) - 2,3-DIHYDROXYBENZALDEHYDE COMPLEX
}

\author{
Ludmila Kiriyak $^{\mathrm{a}}$, Tatiana Cazac ${ }^{\mathrm{a}}$, M. Revenco ${ }^{\mathrm{b}}$, and I. Povar ${ }^{\mathrm{a}^{*}}$ \\ ${ }^{a}$ Institute of Chemistry, Academy of Sciences of Moldova, \\ 3 Academiei str., Chisinau MD-2028, Republic of Moldova \\ ${ }^{b}$ State University of Moldova, 60 A. Mateevici str., Chisinau MD-2009, \\ Republic of Moldova
}

\begin{abstract}
The polarographic catalytic current in acid solutions of Mo(VI), 2,3-dihydroxybenzaldehyde (2,3-DHBA) and chlorate ions has been investigated. The scheme of reactions taking place in the solutions and on the electrode has been elaborated. The increase of the catalytic current is explained by the formation of the active intermediate complex $\left[\mathrm{Mo}(\mathrm{V}) \cdot 2,3\right.$-DHBA $\left.\left(\mathrm{ClO}_{3}^{-}\right)\right]$. The rate constant of formation for the active intermediate complex $\mathrm{K}=2.5 \cdot 10^{6} \mathrm{~mol}^{-1}$ $\cdot \mathrm{dm}^{3} \cdot \mathrm{s}^{-1}$, the activation energy of reaction $\mathrm{E}_{\mathrm{a}}=14.0 \mathrm{kcal} \cdot \mathrm{mol}^{-1}$ and the activation entropy $\Delta \mathrm{S}_{\mathrm{a}}^{\neq}=-28.3$ e.u. have also been determined.
\end{abstract}

Keywords: Voltammetry, catalytic current, molybdenum, 2,3-dihydroxybenzaldehyde, potassium chlorate.

\section{Introduction}

The addition of organic compounds into the polyvalent metal - oxidant system exerts various influences on the catalytic current magnitude. It has been proved that some oxy-acids, catechol and mandelic acid, increase greatly the catalytic activity of $\mathrm{Mo}(\mathrm{VI})$ and $\mathrm{W}(\mathrm{VI})$ while $\mathrm{ClO}_{3}^{-}$or $\mathrm{BrO}_{3}^{-}$ions are used as oxidants [1-4]. The catalytic currents of chlorate and bromate ions have been used to determine several elements $(\mathrm{Mo}, \mathrm{Ti}$, and $\mathrm{Cr}$ ) in a range of objects [5 - 10]. In the review [11] the authors discussed comprehensively the investigations concerning the determination of molybdenum in the presence of such oxidants as $\mathrm{NO}_{3}^{-}, \mathrm{ClO}_{4}^{-}, \mathrm{ClO}_{3}^{-}, \mathrm{BrO}_{3}^{-}$, as well as papers with the preliminary concentration of molybdenum complex compounds with several organic reagents. The authors [12] have shown that complexes $\mathrm{V}(\mathrm{V})$ and $\mathrm{Mo}(\mathrm{VI})$ with 2,5-dyhydroxy-1,4- benzoquinone in solutions of such an oxidant as $\mathrm{ClO}_{4}^{-}$display a great surface activity, thus allows to use this catalytic system for the adsorptive voltammetric determination Mo(VI) and other metal ions [13].

This paper is dedicated to the investigation of the polarographic current nature in solutions of $\mathrm{Mo}(\mathrm{VI})$, chlorate ions and 2,3-DHBA. The main attention is focused on the impact of 2,3-DHBA under the catalytic current in the system $\mathrm{Mo}(\mathrm{VI})-\mathrm{ClO}_{3}^{-}$, as well as on the choice of optimal conditions for determining molybdenum by the value of the catalytic current.

\section{Experimental}

Polarographic measurements were carried out on polarograph PU-1 (Russia) in the thermostated $\left(25 \pm 0.1^{\circ} \mathrm{C}\right)$ threeelectrode cell. The working electrode was the mercury drop electrode (MDE, $2.45 \mathrm{mg}^{2 / 3} \cdot \mathrm{s}^{-1 / 2}$ ), the reference electrode - the saturated calomel (SCE) one and a platinum wire as an auxiliary electrode. The drop-time curves were obtained by measuring drop-time in the three-electrode cell with a slowly dropping capillary $(12 \mathrm{~s})$. The solution acidity was verified by the universal $\mathrm{pH}$-meter OP-104/1 (Hungary). The oxygen was removed from the solution by the electrolytic hydrogen blowing.

The standard solution of molybdenum (VI) was prepared by dilution of the exact weighted amount of the chemically pure $\mathrm{Na}_{2} \mathrm{MoO}_{4} \quad 2 \mathrm{H}_{2} \mathrm{O}$. The purity for other reagents was at least of analytical grade.

Solutions $\mathrm{Na}_{2} \mathrm{SO}_{4}+\mathrm{H}_{2} \mathrm{SO}_{4}(\mathrm{pH} 2.0-2.5)$ served as a supporting electrolyte. Solutions of a smaller concentration were prepared by subsequent dilution of the initial ones.

The standard solution of $1 \cdot 10^{-3} \mathrm{M} 2,3$-DHBA was prepared as follows: the exact weighted portion of 2,3-DHBA was placed in a $100 \mathrm{~cm}^{3}$ volumetric flask; $1.0-1.5 \mathrm{~cm}^{3}$ of ethanol was added and filled up to the mark by means of bidistilled water.

The working solutions were prepared in the following order: 2,3-DHBA was added to the neutral molybdate solution, then the supporting electrolyte and oxidant (potassium chlorate) were added and the necessary $\mathrm{pH}$ value was established.

\section{Results and discussion}

Fig. 1 shows the polarograms of solutions containing $1 \cdot 10^{-5} \mathrm{M} \mathrm{Mo}(\mathrm{VI})$ (curve 2), $5 \cdot 10^{-7} \mathrm{M} \mathrm{Mo}(\mathrm{VI})$ (curve 3 )and $1 \cdot 10^{-4} \mathrm{M} \mathrm{Mo}(\mathrm{VI})$ (curve 4) on sulphuric supporting electrolyte (curve 1) in the presence of $0.2 \mathrm{M} \mathrm{KClO}_{3}$ with $2 \cdot 10^{-5}$ M 2,3-DHBA (curve 3) and without it (curve 2). In the absence of 2,3-DHBA two catalytic waves responding to the reduction of $\mathrm{Mo}(\mathrm{VI})$ to $\mathrm{Mo}(\mathrm{V})$ and of $\mathrm{Mo}(\mathrm{V})$ to $\mathrm{Mo}(\mathrm{III})$ are registered on polarograms, while in the presence of 2,3- 
DHBA, there was observed a great maximum in the area of first peak potentials. At low concentrations of Mo(VI) in solution, only this maximum is registered on polarograms (curve 3).

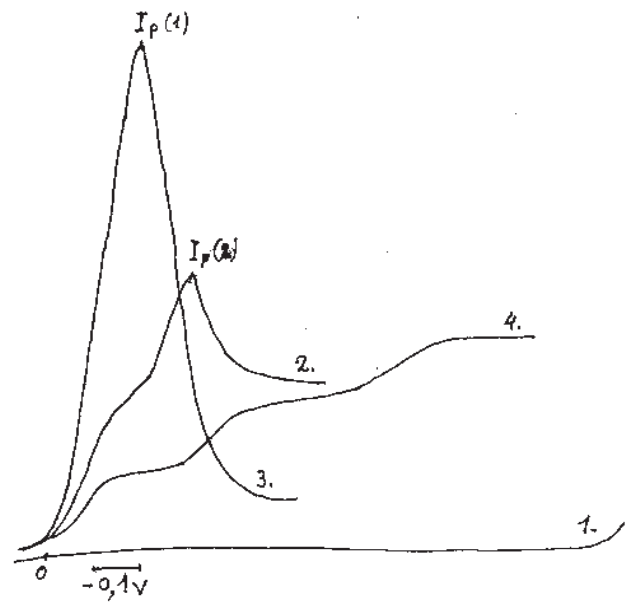

Fig. 1. Polarograms:

1. $\quad 0.1 \mathrm{M} \mathrm{H}_{2} \mathrm{SO}_{4}+0.2 \mathrm{M} \mathrm{Na}_{2} \mathrm{SO}_{4}, \mathrm{pH} 2.3$

2. $1+1 \cdot 10^{-5} \mathrm{M} \mathrm{Mo}(\mathrm{VI})+0.2 \mathrm{M} \mathrm{KClO}_{3}$;

3. $\quad 1+1 \cdot 10^{-7} \mathrm{M} \mathrm{Mo}(\mathrm{VI})+2 \cdot 10^{-5} \mathrm{M} 2,3-\mathrm{DHBA}+0.2 \mathrm{M} \mathrm{KClO}_{3}$;

4. $1+1 \cdot 10^{-4} \mathrm{M} \mathrm{Mo}(\mathrm{VI})$

In order to identity the nature of this maximum, we have studied the influence of the mercury column height above the capillary $\left(\mathrm{h}_{\mathrm{Hg}}\right)$, temperature, $\mathrm{pH}$ values, as well as the 2,3-DHBA, $\mathrm{Mo}(\mathrm{VI})$ and $\mathrm{ClO}_{3}^{-}$concentrations on the maximum current value $\left(\mathrm{I}_{\mathrm{p}}\right)$.

The change of the mercury column height within $45-25 \mathrm{~cm}$ is shown in Fig. 2.

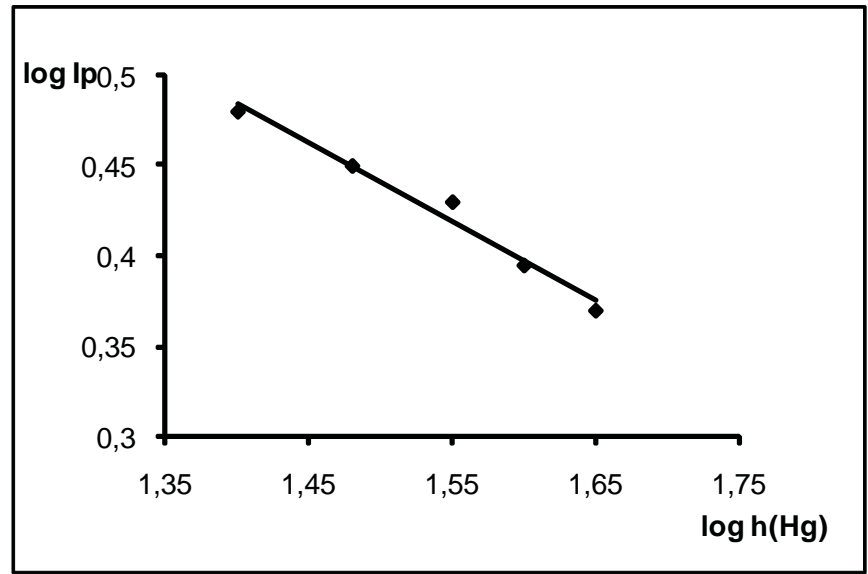

Fig. 2. Dependence of $\mathrm{I}_{\mathrm{p}}$ on $\mathrm{h}_{\mathrm{Hg}}$ for the solution that contains $5 \cdot 10^{-7} \mathrm{M}$ $\mathrm{Mo}(\mathrm{VI}), 2 \cdot 10^{-5} \mathrm{M} 2,3$-DHBA and $0.2 \mathrm{M} \mathrm{KClO}_{3}$ at $\mathrm{pH}=2.3$.

As one can see from Fig. 2, the $I_{p}$ value increases when the height of the mercury column above the capillary decreases. Such dependence is characteristic for electrode processes complicated by reacting substances adsorption on the electrode. The average value of the temperature coefficient in the temperature interval $(20-40)^{\circ} \mathrm{C}$ is $7 \% /$ degree which points out to the catalytic nature of the current.

Dependence of the $\mathrm{I}_{\mathrm{p}}$ value on the concentration of oxidant $\left(\mathrm{ClO}_{3}^{-}\right)$in the form of a curve with a bend and a saturation section (Fig. 3., curve 1) proves the formation of a polarographically active complex that is characteristic for catalytic currents.

The curve showing the dependence of $I_{p}$ on the ligand concentration passes through the maximum. The ligand activated action increases with the concentration growth (at its low concentrations), then it decreases.

The ligand (activator) availability in the catalyst coordination sphere contributes to the acceleration of the reaction of polarographically active mixed complex formation if in the catalyst coordination sphere there is enough space for the substrate (oxidant) entry, consequently the catalytic current increases. If in the catalyst - activator - substrate (Mo(VI) - 2,3-DHBA- $\mathrm{ClO}_{3}^{-}$) system there are conditions when the ligand blocks all the catalyst coordination places, then the 
catalytic activity decreases and the current drops. The maximum value of the current is observed when the concentration of 2,3 -DHBA is equal to $2 \cdot 10^{-5} \mathrm{M}$.

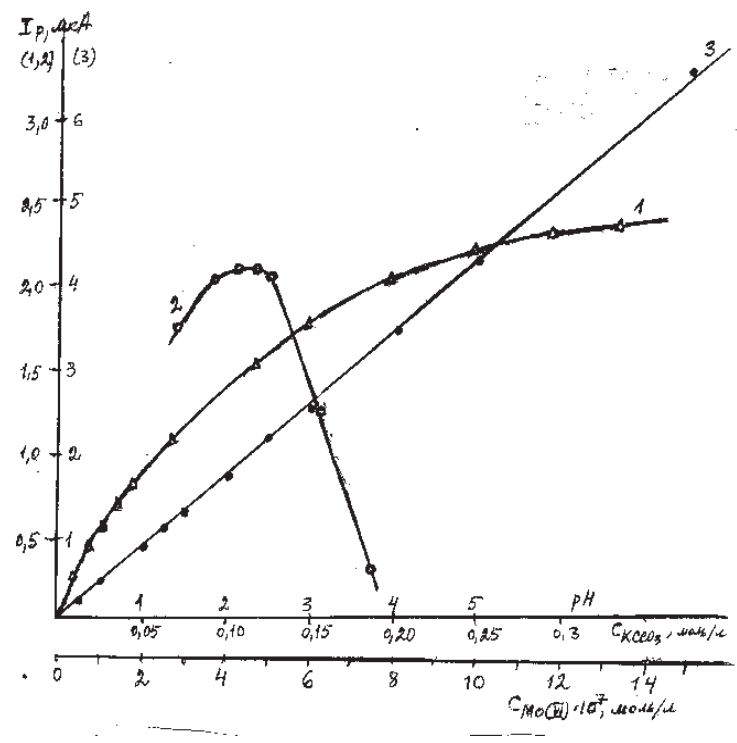

Fig. 3. Dependence of $1_{\mathrm{p}}$ on the concentration of $\mathrm{KClO}_{3}(1), \mathrm{pH}(2)$ and the $\mathrm{Mo}(\mathrm{VI})$ concentration (3):

2. $5 \cdot 10^{-7} \mathrm{M} \mathrm{Mo}(\mathrm{VI}), 2 \cdot 10^{-5} \mathrm{M} 2,3-\mathrm{DHBA}$ and $0.2 \mathrm{M} \mathrm{KClO}_{3}$;

\section{3. $2 \cdot 10^{-5} \mathrm{M} 2,3$-DHBA, $0,2 \mathrm{M} \mathrm{KClO}_{3}$ and $\mathrm{pH} 2.3$.}

The influence of $\mathrm{pH}$ on $\mathrm{I}_{\mathrm{p}}$ (Fig. 3, curve 2), as for other ligands, is manifested through the influence of $\mathrm{pH}$ on the complexing organic ligand dissociation or its protonization, as well as on the molybdenum active particles concentration in solution. Besides, the hydrogen ions participate in the oxidation - reduction process leading to the depolarizer regeneration. While the $\mathrm{pH}$ value increases, the potential of the maximum peak shifts towards more negative values.

The catalytic wave unusual shape in the form of a high maximum in solutions containing molybdenum $(\mathrm{VI}), \mathrm{ClO}_{3}^{-}$ and the organic ligand can be explained by adsorption of all the components of the catalytic system on the electrode, this being shown by the dependence of drop - time of the capillary upon the electrode potential (Fig.4), but mainly by the higher rate of the chemical reaction running at the mercury - solution interface and determining the catalytic process rate on the whole.

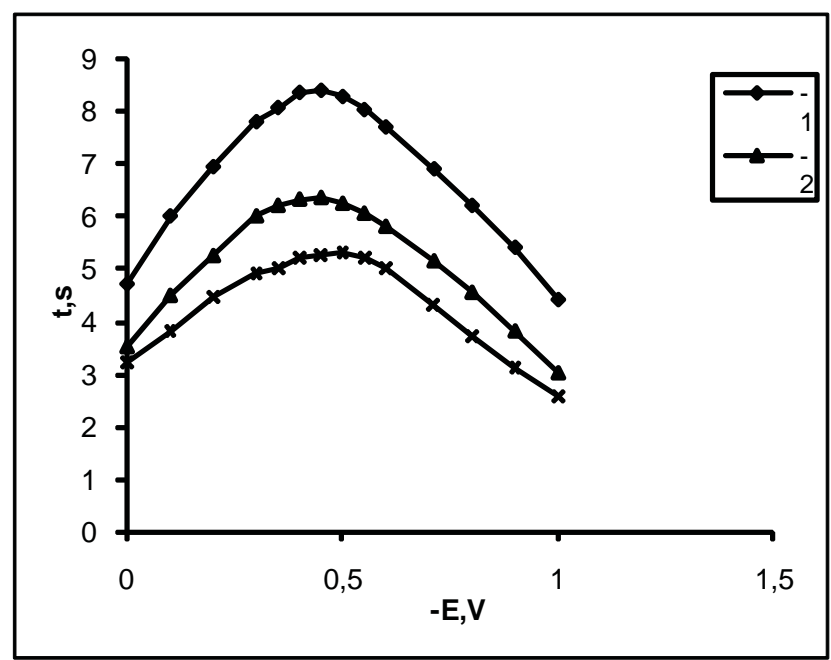

Fig. 4. Drop - time curves:

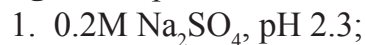

2. $1+2 \cdot 10^{-7} \mathrm{M} \mathrm{Mo}(\mathrm{VI}), 2 \cdot 10^{-5} \mathrm{M} 2,3$-DHBA and $\mathrm{pH} 2.3$; 3. $2+0.2 \mathrm{M} \mathrm{KClO}_{3}$ and $\mathrm{pH} 2.3$. 
The analysis of experimental dependences of the catalytic current from the solution acidity and the concentration of catalytic system components (e.g. the catalyst, organic ligand and oxidant) has allowed representing the catalytic process by a scheme of subsequent chemical and electrochemical stages:

1. The complex formation of $\mathrm{Mo}(\mathrm{VI})$ with the organic ligand (L) in solution (the charges of complex species are dropped)

$$
\mathrm{Mo}(\mathrm{VI})+\mathrm{L} \leftrightarrow[\mathrm{Mo}(\mathrm{VI}) \mathrm{L}]+\mathrm{H}^{+}
$$

2. The catalyst formation

$$
[\mathrm{Mo}(\mathrm{VI}) \mathrm{L}]+\mathrm{e} \rightarrow[\mathrm{Mo}(\mathrm{V}) \mathrm{L}]
$$

3. The formation of the intermediate active complex with an oxidant

$$
[\mathrm{Mo}(\mathrm{V}) \mathrm{L}]+\mathrm{ClO}_{3}^{-} \leftrightarrow\left[\mathrm{Mo}(\mathrm{V}) \mathrm{L}\left(\mathrm{ClO}_{3}^{-}\right)\right] \leftrightarrow\left[\mathrm{Mo}(\mathrm{V}) \mathrm{L}\left(\mathrm{ClO}_{3}^{-}\right)\right]_{\text {ads }}
$$

4. The catalyst redox - regeneration.

As it has been shown by the authors [14] on the example of the $\mathrm{Mo}(\mathrm{VI})+\mathrm{H}_{2} \mathrm{C}_{2} \mathrm{O}_{4}+\mathrm{ClO}_{3}^{-}$catalytic system, the catalyst redox - regeneration can proceed in two ways:

a) In the polarographically active complex $\left[\mathrm{Mo}(\mathrm{V}) \mathrm{L}\left(\mathrm{ClO}_{3}^{-}\right)\right]$the electronic charge transfer on the substrate $\left(\mathrm{ClO}_{3}{ }^{-}\right.$ ), followed by the catalyst in the highest oxidation degree intra - complex oxidation and regeneration, take place.

$\left[\mathrm{Mo}(\mathrm{V}) \mathrm{L}\left(\mathrm{ClO}_{3}^{-}\right)\right]_{\text {ads }}+2 \mathrm{H}^{+} \rightarrow[\mathrm{Mo}(\mathrm{VI}) \mathrm{L}]+\mathrm{ClO}_{2}^{-}+\mathrm{H}_{2} \mathrm{O}$

b) The electronic density shift from the substrate $\left(\mathrm{ClO}_{3}^{-}\right)$to the catalyst in the polarographically active complex occurs. As a result, the catalyst catalytically active form is regenerated in the lowest oxidation degree.

$\left[\mathrm{Mo}(\mathrm{V}) \mathrm{L}\left(\mathrm{ClO}_{3}^{-}\right)\right]_{\text {ads }}+\mathrm{e}+2 \mathrm{H}^{+} \rightarrow[\mathrm{Mo}(\mathrm{V}) \mathrm{L}]+\mathrm{ClO}_{2}+\mathrm{H}_{2} \mathrm{O}$

The obtained polarographic data do not allow making a conclusion concerning the catalyst regeneration in any form. Nevertheless, it is necessary to emphasize that at ligand low concentrations $\left(<3 \cdot 10^{-5} \mathrm{M}\right)$ one high sharp maximum with a peak potential corresponding to the first wave of complex $\mathrm{Mo}(\mathrm{VI})$ reduction into $\mathrm{Mo}(\mathrm{V})$ is registered on polarograms, so the preference should be given to the first mechanism. With the increase of ligand concentration $\left(>5 \cdot 10^{-5} \mathrm{M}\right)$ the peak bifurcates and, at the further increase of ligand concentration $\left(1 \cdot 10^{-4} \mathrm{M}\right)$ the second maximum becomes slightly higher than the first one. It is quite possible that this phenomenon can be also explained by the catalyst regeneration in the lowest oxidation degree. Additionally, the authors [12] noted that at the (2,5-dichloro-3,6-dihydroxy-1,4-benzoquinone) ligand concentration of $5 \cdot 10^{-5} \mathrm{M}$, one maximum is registered while at the ligand concentration growth the peak decreases and its potential changes. Also, for the $\mathrm{Mo}(\mathrm{VI})$ - catechol $-\mathrm{ClO}_{3}{ }^{-}$system, it was pointed out that the catalytic current in the form of a peak was observed in the case of ligand small concentrations (Fig. 1, curve 3) [1]. At the $5 \cdot 10^{-2} \mathrm{M}$ catechol concentration, the peak becomes wide without a clearly expressed peak and the current decrease is observed at more negative potentials (Fig. 1, curve 4 [1]). It is quite possible that in this case the catalyst regeneration occurs according to the abovementioned mechanisms. The maximum shape change, generated by the ligand concentration growth, can also be connected with a smaller deficit in the ligand molecule layer close to the electrode-solution interface necessary for the intermediate active complex formation. It may also be due to a stronger influence of the ligand and Mo(VI) complex electrode surface adsorption on the electrochemical depolarizer reduction (Fig. 4, curves 2 and 3).

The rate constant of the $\left[\mathrm{Mo}(\mathrm{V}) \mathrm{L}\left(\mathrm{ClO}_{3}^{-}\right)\right]$intermediate active complex formation has been calculated by Koutetski's equation $\mathrm{I}_{\mathrm{k}} / \mathrm{I}_{\mathrm{d}}=0,81 \sqrt{\mathrm{nKC}_{\mathrm{s}} \mathrm{t}} \quad$ in solutions with $2 \cdot 10^{-5} \mathrm{M}$ concentration of 2,3-DHBA in the linear $\mathrm{I}_{\mathrm{p}}-\mathrm{C}^{1 / 2}\left(\mathrm{ClO}_{3}^{-}\right)$dependence area (where $\mathrm{I}_{\mathrm{k}}$ is the catalytic current equal to $\mathrm{I}_{\mathrm{p}}-\mathrm{I}_{\mathrm{d}} ; \mathrm{I}_{\mathrm{d}}$ - diffusion reduction current of the process $[\mathrm{Mo}(\mathrm{VI}) \mathrm{L}]+\mathrm{e} \rightarrow[\mathrm{Mo}(\mathrm{V}) \mathrm{L}]$, recalculated for the $5 \cdot 10^{-7} \mathrm{M}$ concentration of $\mathrm{Mo}(\mathrm{VI})$ and $t$ is dropping time, 3.6s) (Fig. 5, Table 1).

Table 1

Rate constants of complex $\left[\mathrm{Mo}(\mathrm{V}) \mathrm{L}\left(\mathrm{ClO}_{3}^{-}\right)\right]$formation

\begin{tabular}{|c|c|c|c|}
\hline $\mathrm{C}^{1 / 2}\left(\mathrm{KClO}_{3}\right), \mathrm{M}$ & $\mathrm{I}_{\mathrm{p}}, \mathrm{mkA}$ & $\mathrm{I}_{\mathrm{p}} / \mathrm{I}_{\mathrm{d}}$ & $\mathrm{K} \cdot 10^{6}, \mathrm{~mol}^{-1} \cdot \mathrm{dm}^{3} \cdot \mathrm{c}^{-1}$ \\
\hline 0.22 & 1.02 & 509 & 2.2 \\
0.26 & 1.28 & 639 & 2.5 \\
0.30 & 1.44 & 719 & 2.4 \\
0.39 & 1.85 & 924 & 2.4 \\
0.44 & 2.30 & 1149 & 2.8 \\
\hline
\end{tabular}




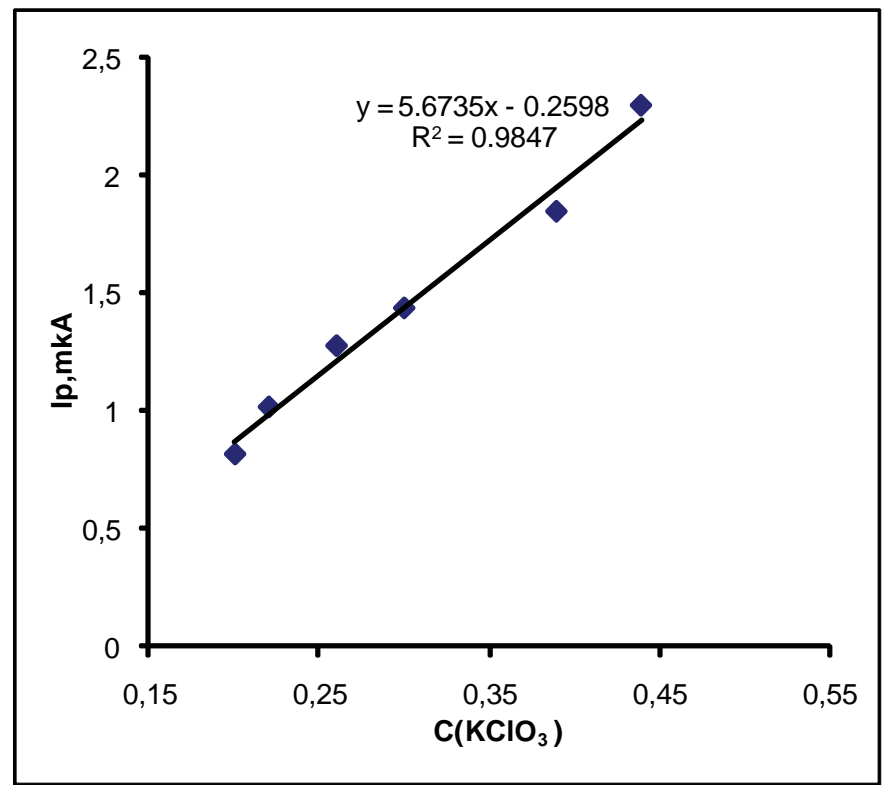

Fig. 5. Dependence of $\mathrm{I}_{\mathrm{p}}$ on $\mathrm{C}^{1 / 2}\left(\mathrm{KClO}_{3}\right)$ for the solutions with $5 \cdot 10^{-7} \mathrm{M} \mathrm{Mo}(\mathrm{VI})$, $2 \cdot 10^{-5} \mathrm{M} 2,3$-DHBA and $\mathrm{pH} 2.3$.

The activation energy and entropy of the catalytic process (Table 2) have been determined from the $\log \mathrm{K}-1 / \mathrm{T}$ dependence [15] for the $20-40^{\circ} \mathrm{C}$ temperature interval (Fig. 6).

Table 2

Kinetic and thermodynamic characteristics of the catalytic processes in the solutions of $M o(V I)$ with 2,3-DHBA Catechol , $\mathrm{H}_{2}$ Glucar or HMandel complexes

\begin{tabular}{|l|c|c|c|c|}
\hline \multicolumn{1}{|c|}{ Ligand - activator } & $\begin{array}{c}\mathrm{K} \cdot 10^{6}, \\
\mathrm{~mol}^{-1} \cdot \mathrm{dm}^{3} \cdot \mathrm{s}^{-1}\end{array}$ & $\mathrm{E}, \mathrm{kcal} / \mathrm{mol}$ & $\Delta \mathrm{S}_{\mathrm{a}}{ }^{*}$, e.u. & References \\
\hline 2,3-DHBA & 2.5 & 14.0 & -28.3 & - \\
Catechol & 8.2 & 16.6 & -26.0 & {$[1]$} \\
$\mathrm{H}_{2}$ Glucar & 7.6 & 9.3 & -27.4 & {$[1]$} \\
HMandel & 220 & 14.3 & -20.4 & {$[3]$} \\
\hline
\end{tabular}

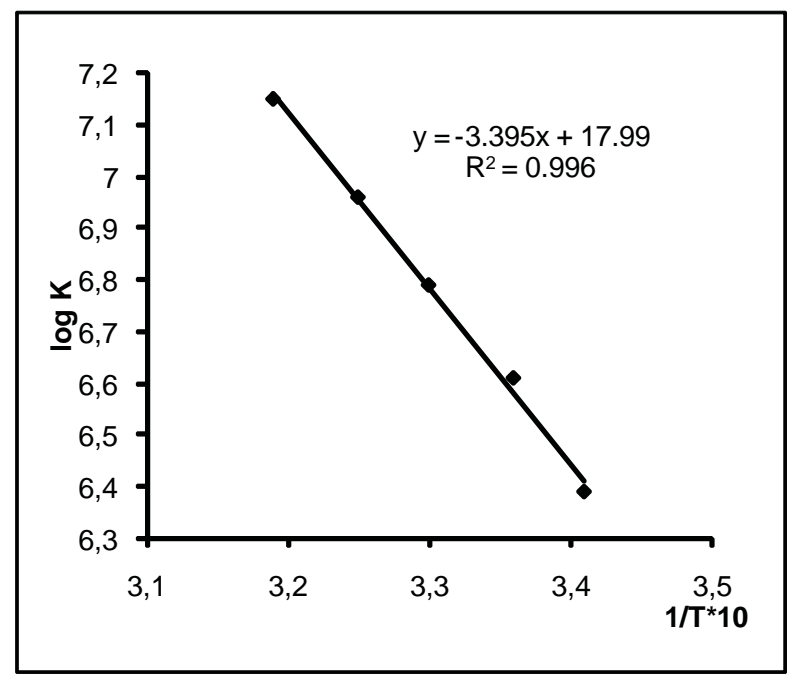

Fig. 6. Dependence of $\log \mathrm{K}$ on $1 / \mathrm{T}$ for the solution of $5 \cdot 10^{-7} \mathrm{M} \mathrm{Mo}(\mathrm{VI}), 2 \cdot 10^{-5} \mathrm{M} 2.3-\mathrm{DHBA}, 0.2 \mathrm{M} \mathrm{KClO}_{3}$ and $\mathrm{pH} 2.3$.

The calculated rate constant of intermediate active complex formation, activation energy and entropy demonstrate the high catalytic activity of the studied system. The activation influence of 2,3-DHBA slightly differs from catechol and 
glucaric acid due to the addition of ethyl alcohol for a better solubility of 2,3-DHBA, being considerably smaller than for mandelic acid (Table 2). The large negative activation entropy values indicate on the spatial difficulties that occur when $\mathrm{ClO}_{3}^{-}$ions are introduced into the $\mathrm{Mo}(\mathrm{V})$ complex coordination sphere. As one can see from the entropy activation $\Delta \mathrm{S}_{\mathrm{a}}^{\neq}$values, the introduction of $\mathrm{ClO}_{3}^{-}$ions into the coordination sphere of $\mathrm{Mo}(\mathrm{V})$ complexes with mandelic acid is the easiest, so the influence of the HMandel activation is higher than for other ligands [1-3].

The catalytic reaction in the $\mathrm{Mo}(\mathrm{VI})$ - 2,3-DHBA - $\mathrm{ClO}_{3}{ }^{-}$system is quite selective and may serve for the metal - catalyst micro-quantities determination. The optimal conditions of this determination are: $2 \cdot 10^{-5} \mathrm{M} 2,3-\mathrm{DHBA}$, $0.2 \mathrm{M} \mathrm{ClO}_{3}, 0.2 \mathrm{M} \mathrm{Na}_{2} \mathrm{SO}_{4}$ and $\mathrm{pH} 2-2,3$. The dependence of $\mathrm{I}_{\mathrm{p}}$ on the $\mathrm{Mo}(\mathrm{VI})$ concentration in the solution within $(1-15) \cdot 10^{-7} \mathrm{M}$ is shown in Fig. 3 (curve 3).

\section{Conclusions}

This study describes the polarographic catalytic current behavior in acid solutions containing Mo(VI), 2,3-dihydroxybenzaldehyde (2,3-DHBA) and chlorate - ions. From the results of the measurements the scheme of reactions occurring in the solution and on the electrode has been elaborated. The catalytic current increase in the presence of 2,3-DHBA is explained by the formation of the active intermediate complex $\left[\mathrm{Mo}(\mathrm{V}) \cdot 2,3-\mathrm{DHBA}\left(\mathrm{ClO}_{3}^{-}\right)\right]$. The rate constant of the intermediate active complex reaction formation $\mathrm{K}=2.5 \cdot 10^{6} \mathrm{~mol}^{-1} \cdot \mathrm{dm}^{3} \cdot \mathrm{s}^{-1}$, as well as the reaction activation energy $\mathrm{E}_{\mathrm{a}}=14.0 \mathrm{kcal} \cdot \mathrm{mol}^{-1}$ and the activation entropy $\Delta \mathrm{S}_{\mathrm{a}}^{\neq}=-28.3$ e.u. have been determined. Further research will focus on the established possibility of the Mo(VI) small quantities determination.

\section{Acknowledgments}

This work was done under the support of the SCOPES 2009-2012 joint research grant.

\section{References}

[1]. CHIKRYZOVA, E.G.; KIRIYAK, L.G., Zh. Anal. Khim. 1974, 29, 2420 - 2426.

[2]. CHIKRYZOVA, E.G.; KIRIYAK, L.G., Zh. Anal. Khim. 1980, 35, 492-499.

[3]. BARDINA, S.M.; CHIKRYZOVA, E.G., Zh. Anal. Khim. 1978, 32, 358.

[4]. TOROPOVA, V.F.; KOPYLOVA, O.V., Zh. Anal. Khim. 1977, 32, 1159.

[5]. SAFARI, A.; SHARNS, E., Anal. Chem. Acta. 1999, 396, 215 - 220.

[6]. YOKOIL, K.; VAN DEN BERG, C.M.G., Anal. Chem. Acta. 1992, 257, 293 - 299.

[7]. KOCHELAEVA, G.A.; IVANOV, V.M.; PROKHOROVA, G.V., Zh. Anal. Khim. 2001, 56, 860 - 866.

[8]. TOROPOVA, V.F.; POLYAKOVA, IU.N.; MALTSEVA, I.I., MIKRUKOVA, E. IU., Zh. Anal. Khim. 1999, 45, $272-279$.

[9]. BOBROWSKI, A.; BAS, B.; DOMINIK, J., NIEWIARA, E. ; SZALINSKA, E.; VIGANDI, Z; ZAREBSKI, J., Talanta. 2004, 63, $1003-1012$.

[10]. FITSEV, I. M.; TOROPOVA, V. F.; ROMADANSKAYA, E.V., ANISIMOVA, L.A., Zh. Anal. Khim. 1999, 54, $510-512$.

[11]. IVANOV, V.M.; KOCHELAEVA, G.A.; PROKHOROVA, G.V., Zh. Anal. Khim. 2002, 57, 902 - 917.

[12]. NOVOTNY, L.; NAVRATIL, T,; SANDER, S.; BASOVA, P., Electroanalysis, 2002, 14, 1105 - 1109.

[13]. SANDER, S., Anal. Chim. Acta., 1999, 394, 81 -89.

[14]. BERSUKER, I.B.; BARDINA, S.M., Theor. Exp. Chim., 1978, 13, 455 - 463.

[15]. KOLDIN, E., Quick reactions in the solutions. M.: Mir, 1966, p. 285. 